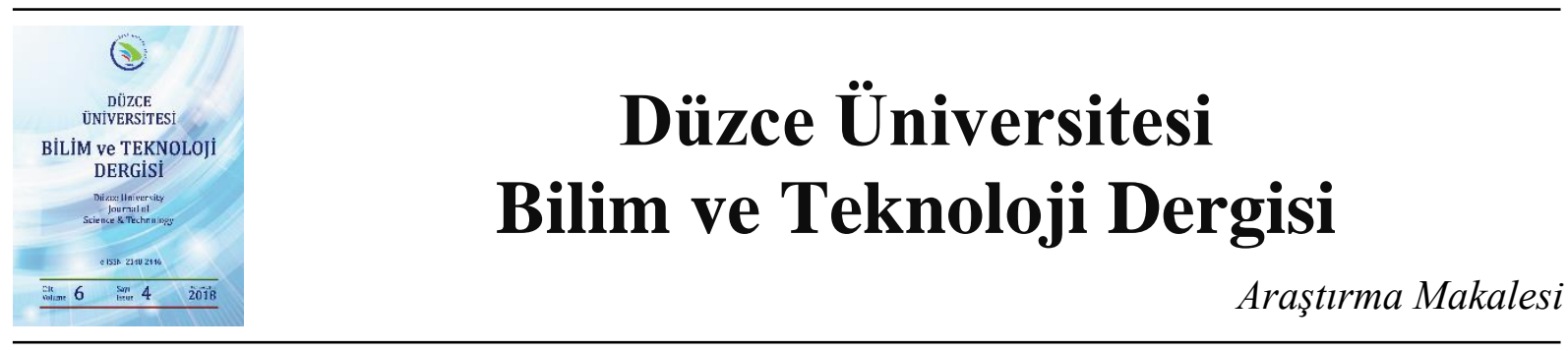

\section{Kentsel Açık Mekanlarda Kullanıcı Memnuniyeti Değerlendirmesi : Adapazarı Kent Park Örneği}

\author{
Cansın KAHYA ${ }^{\text {a, }}$, Özgür YERLİ ${ }^{\text {a }}$ \\ ${ }^{a}$ Peyzaj Mimarlığı Bölümü, Orman Fakültesi, Düzce Üniversitesi, Düzce, TÜRKIYE \\ * Sorumlu Yazarin e-posta adresi: cansinkahya@gmail.com
}

\begin{abstract}
ÖZET
Bu çalışmada alansal büyüklük bakımından, Adapazarı kentinde bulunan en büyük yüzölçümüne sahip park olan "Kent Park" incelenmiştir. Çalışmanın amacı, Kent Park'ın kullanıcı isteklerini ne derecede karşıladığının belirlenmesi ve böylece sürdürülebilir kullanımlarının mekan kalitesi açısından ele alınmasına yönelik öneriler getirmektedir. Bu çalışma kapsamında 120 kişiye uygulanan anketlerden elde edilen veriler doğrultusunda kullanıcıların en çok tercih ettiği etkinlikler, alana gelmeden önceki ve geldikten sonraki beklentileri yapılan analizler sonucunda tespit edilmiştir. Rekreasyonel motivasyonların belirlenmesinde beş noktalı Likert Ölçeği'nden yararlanılmıştır. Faktör analizi sonucunda iki adet motivasyon faktör grubu tespit edilmiştir. Buna göre alanın teknik ve estetik özellikleri kullanıcıların rekreasyonel faaliyetlere katılımlarını daha fazla motive etmektedir. Analiz sonuçlarına göre Kent Park kullanıcılarının, alana gelmeden önce beklentilerinin yüksek olduğu, alana geldikten sonra parkın beklentilerini karşılamadığı sonucuna ulaşılmıştır.
\end{abstract}

Anahtar Kelimeler: Kullanıcı memnuniyeti, Kent, Açık mekan, Kent park.

\section{Evaluation of User Satisfaction in Urban Open Spaces: Case of Adapazarı Kent Park}

\begin{abstract}
In this study, "Kent Park" which is the park with the greatest surface area in Adapazarı was examined in terms of area size. The aim of the work is to determine how Kent Park users are satisfied from the expectations and thus to make suggestions for the sustainable use of the park in terms of space quality. Within the scope of this study, the most preferred activities of the users in the direction of the data obtained from the questionnaires applied to 120 persons were determined as the results of the analyzes before and after coming to the field. The five-point Likert Scale was used to identify recreational motivations. Two motivation factor groups were identified as a result of factor analysis. According to the analysis, the technical and aesthetic qualities of the area motivate users more to participate in recreational activities. According to the results of the analysis, it was found that Kent Park users had high expectations before arriving in to the area but after the users came to the area, their expectations were not met.
\end{abstract}

Keywords: User satisfaction, Urban, Open space, Kent Park. 


\section{GiRiș}

$\dot{\mathrm{I}}_{\mathrm{s}}^{\mathrm{n}}$ nsan, çevresi içinde hem fiziksel bir obje, hem de yaşayan bir organizmadır. Fiziksel bir obje olarak ölçüsüyle, yoğunluğuyla ve şekli ile bir özellik kazanmakta; gerek bulunduğu çevreyi oluşturan bir eleman olarak ona karşı tepkide bulunmakta ve gerekse çevresi tarafindan yönlendirilmektedir [1]. Bu sebeple bir taraftan kendi gereksinme, değer ve isteklerine göre çevresini değiştirmekte; diğer taraftan da değiştirilmiş çevreden kaynaklanan kişilik ve ruhsal yapısını etkileyen yeni gereksinimlere sahip olmaktadır [2].

Kullanıcı gereksinimleri, kullanıcının bir mekan içinde yaşamını toplumsal, psikolojik ve fizyolojik rahatsızlıklara uğramadan sürdürülebileceği ve yaptığı işlerde verimli olmasına yardım edecek olanakları sağlayan çevre koşulları şeklinde tanımlanmaktadır [3]. Başarılı kentsel açık mekanların oluşturulması, kullanıcı ihtiyaç ve gereksinimlerinin karşılanmasına bağlıdır. Dolayısıyla başarısız, yani kullanılmayan kentsel açık mekanların sorunu, kullanıcı istekleri ile uyuşmuyor olmasıdır [4]. Bu sebeple kentsel açık mekanlar oluşturulurken öncelikle kullanıcı ihtiyaç ve gereksinimlerinin tespit edilmesi gerekmektedir. Carr vd. (1992), kentsel açık mekanlarda kullanıcı ihtiyaç ve gereksinimlerini beşe ayırmıştır. Bunlar; aktif etkinlikler, pasif etkinlikler, konfor, dinlenme ve keşfetmedir [5].

Performans kavramı, kullanıcı ihtiyaç ve gereksinimlerini karşılama düzeyidir. Ayrıca "bir mekanın ölçülebilen davranışı" olarak da tanımlanabilir [6]. Performans seviyesi mekan kalitesinin ve dolayısıyla kullanıcı memnuniyetinin bir göstergesidir. Preiser, Rabinowitz, White (1988) kullanıcı memnuiyetini belirlemede kullanılan performans boyutlarının üç bileşenden oluştuğunu belirtmiştir. Performans boyutlarının değerlendirilmesi, olumlu yönde değişikliklere gidilmesi ve mevcut mekanın niteliklerinin tespit edilmesi anlamında yarar sağlarken, bir yandan da yeni oluşumlarda olumsuzlukları en aza indirgemek adına programlama kriterlerini belirlemede yol gösterici olmaktadır. Bunlar teknik performans, işlevsel performans ve estetik performans boyutlarıdır [7].

Teknik performans boyutu (döşeme elemanları, donatı elemanları, su öğeleri ve kapalı fonksiyon mekanları) mekanın öğe ve bileşenlerine odaklı yapısal performans olarak tanımlanmaktadır. $\mathrm{Bu}$ mekan öğe ve bileşenlerinin temiz olması, bakımlı olması, yapım kalitesi, dayanıklılığı teknik performans kriterleridir. İşlevsel performans; etkinliklerin çeşitliliği, etkinlik mekanları, donatı elemanları, yeşil alanlar, kapalı fonksiyon mekanlarının yeterliliği, etkinliklere ulaşımda süreklilik, donatı elemanlarının konforu, etkinlik mekanlarının amacına uygunluğu, güvenlik, bütünlük ve süreklilik gibi kavramları içerir. Estetik performans ise döşeme elemanları, donatı elemanları yeşil alanların biçim, doku ve renk açısından uyumu, bütünlüğü ve sürekliliği kavramlarını içerir. $\mathrm{Bu}$ kavramlar kullanıcı memnuniyetini belirlemek için araştırmada kullanacağımız performans kriterleridir (Tablo 1), [2].

Tablo 1. Performans kriterleri [2].

\begin{tabular}{|c|c|c|}
\hline Teknik Performans & İşlevsel Performans & Estetik Performans \\
\hline \multirow{7}{*}{$\begin{array}{l}\text { Döşeme elemanları } \\
\text { Donatılar } \\
\text { • } \\
\text { • Örurma elemanları elemanları } \\
\text { - } \\
\text { - } \\
\text { Çöp kutınlatma elemanları elemanları }\end{array}$} & Etkinlik mekanlarının çeşitliliği, & \multirow{7}{*}{$\begin{array}{l}\text { Etkinlik mekanları, döşeme } \\
\text { elemanları, donatılar, yeşil alanlar } \\
\text { ve kapalı fonksiyon mekanlarının } \\
\text { biçim ve renk açısından uyumu } \\
\text { Etkinlik mekanları, döşeme } \\
\text { elemanları, donatılar, yeşil alanlar } \\
\text { ve kapalı fonksiyon mekanlarının }\end{array}$} \\
\hline & mekanları, & \\
\hline & elemanları, yeşil alanlar ve kapalı & \\
\hline & fonksiyon mekanlarının yeterliliği & \\
\hline & Etkinlilerle ulaşımda süreklilik & \\
\hline & Donatı elemanlarının konforu & \\
\hline & mekanlarının & \\
\hline
\end{tabular}




\begin{tabular}{|c|c|c|}
\hline 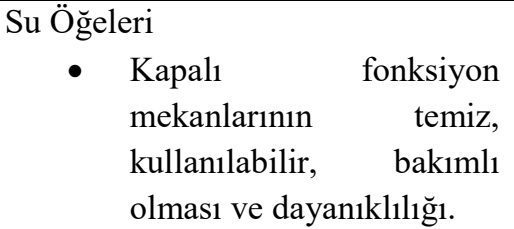 & $\begin{array}{l}\text { donatıların amacına uygunluğu } \\
\text { Güvenlik } \\
\text { Süreklilik } \\
\text { Bütünlük }\end{array}$ & $\begin{array}{l}\text { biçim ve renk açısından bütünlük } \\
\text { ve sürekliliği }\end{array}$ \\
\hline
\end{tabular}

Canter ve Ress (1982), memnuniyet kavramını, mekanın kullanıcıların hedeflerine ulaşmasına yardımcı olma düzeyinin bir yansıması olarak yorumlamışlardır [8]. Kullanıcı memnuniyetinin değerlendirilmesi çalışmalarında, öncelikle mekanın birey tarafından değerlendirilmesi söz konusudur.

İdeal çevre ile algılanan çevre özelliklerinin örtüşme seviyesine bağlı olarak yaşanan yerden memnuniyet seviyesi saptanmaktadır. Bu bağlamda kalite ve memnuniyet kavramlarının birey ve birey-mekan ilişkilerinden etkilendiği söylenebilir. Memnuniyet, bireyin beklenti, ihtiyaç ve kazanımlarıyla ilgili olarak yaşam çevresini değerlendirmesi anlamına gelmektedir. $\mathrm{Bu}$ sebeple bireylerin, aynı mekana ait memnuniyetleri değerlendirildiğinde farklılıklar oluşabileceği bilinmektedir. Bu farkl11ık; daha önce yaşanan mekan, algılama şekli, sosyal ve ekonomik statü, daha iyi şartlarda yaşama isteğine inanç, eğitim düzeyi gibi kişiden kişiye değişen faktörlerden meydana gelmektedir [9].

Memnuniyet, davranışların bir göstergesidir ve bireyin davranışı memnuniyet duygusundan etkilenmektedir [10]. Mekanların kullanım sonrası değerlendirilmesinde memnuniyet kavramı, bir ölçüt olarak kabul edilmektedir. Bunun sebebi, mekan ve kullanıcı etkileşiminde, kullanıcılar ihtiyaç ve gereksinimleri doğrultusunda bulundukları mekanda davranışa yönelirler. Bu davranış memnuniyet derecesine göre meydana gelmektedir. Bu tatmin düzeyinin kişiyi davranışa yöneltmesinin sebebi, fiziksel mekanı kontrol edebilmek ve kendi gereksinimlerine özgü kılma arzusudur. Bu da memnuniyetin ilk koşuludur. Eğer bireyin beklenti ve ihtiyaçları çevre tarafından karşılanıyorsa yüksek seviyede memnuniyet oluşturmakta ve yaşam kalitesi artmaktadır [11]. Kullanıcılar memnun olduğu mekanı kullanırlar. Memnuniyetsizlik oluşturan mekanları ise değiştirme isteği ile mekanı terk ederler. Bu sebeple, memnuniyet kavramı kullanım sonrası değerlendirme çalışmalarında, mekanların daha kullanılabilir ve yaşanılabilir olması için son derece önemlidir.

Mekanın yaşanılabilirliği ve kalitesi; kullanıcı ihtiyaç ve gereksinimleri karşısında gösterdiği performansa bağlıdır [7]. Mekan kalitesinin sağlanabilmesi için öncelikle kullanıcı ihtiyaç ve gereksinimlerinin karşılanma düzeyinin, yani mekan performansının belli kriterlere göre ortaya koyulması gerekir. Çünkü kullanıcı ihtiyaç ve gereksinimlerini karşılayan mekanın performansı yükselir, sonuçta kalite sağlanmış olur. Kalite artarsa, mekan karşısında kullanıcının memnuniyeti de artar. Böylelikle daha yaşanılabilir ve kullanılabilir mekanlar meydana gelir.

$\mathrm{Bu}$ çalışma kapsamında kentsel açık mekanın, kullanıcı ile ilişkisi, insan-çevre etkileşimi kapsamında açıklanmıştır. Dolayısıyla oluşturulan kentsel açık mekandaki kullanıcıların, ihtiyaç ve gereksinimleri doğrultusunda mekana verdikleri tepkiler ele alınmıştır. Mevcut mekandaki kullanıcı memnuniyeti değerlendirilerek, o mekanın daha kullanılabilir bir mekan haline dönüştürülmesi için öneriler getirilmektedir. 


\section{MATERYAL VE YÖNTEM}

\section{A. ÇALIŞMA ALANI}

Çalışma alanı olarak seçilen Kent Park, Sakarya İli, Adapazarı İlçesi sınırları içerisinde yer almaktadır (Şekil 1). Adapazarı kenti içinde bulunan $160.000 \mathrm{~m}^{2}$ lik yüzölçümüyle alansal büyüklük bakımından kentin en büyük parkı olma özelliğine sahiptir.

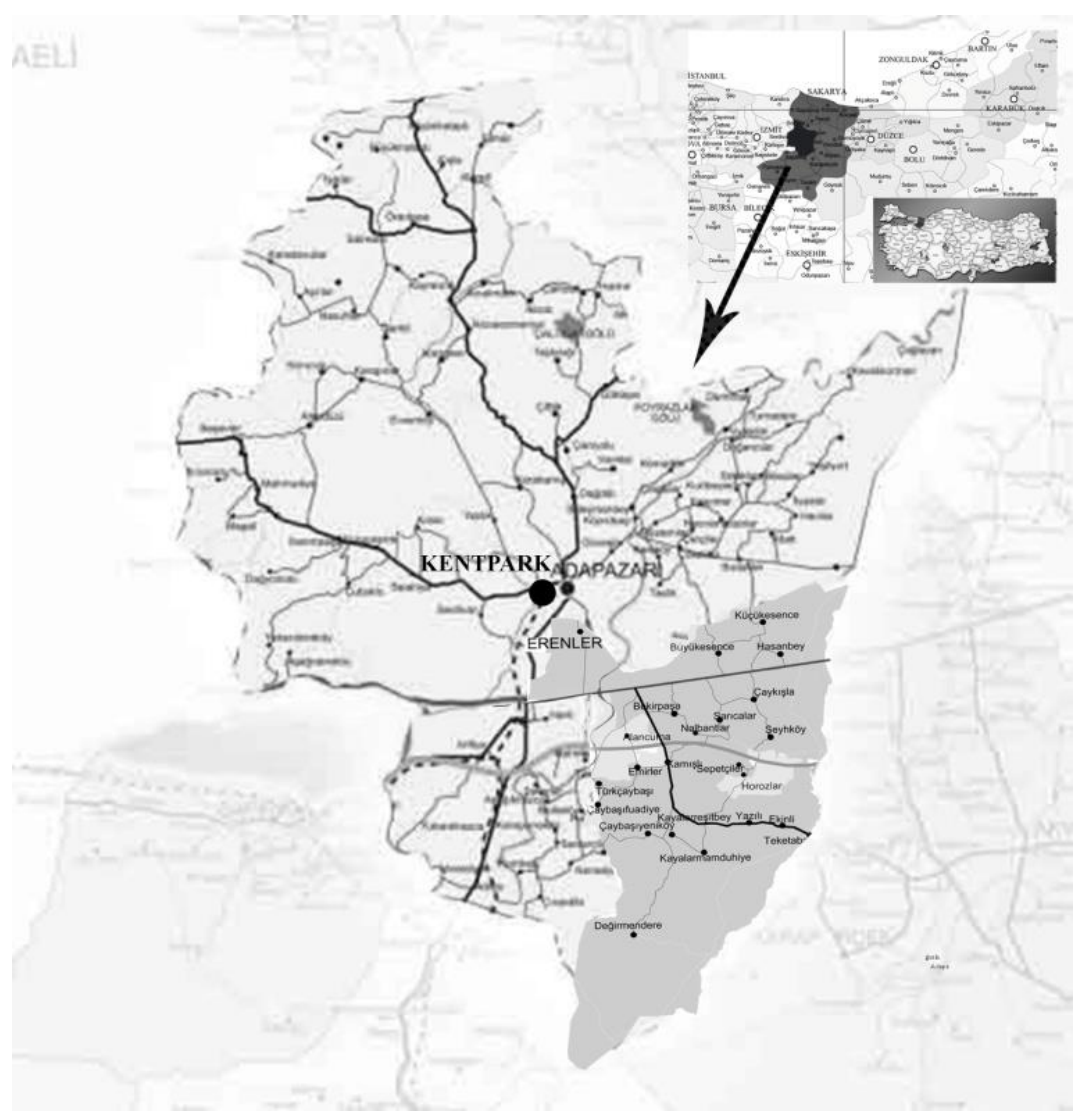

Şekil 1. Çalışma alanının konumu.

Kent Park, toplamda 4500 metre uzunluğunda yürüyüş yollarına sahip olmasının yanı sıra park içerisinde Sakarya'nın simgelerinden olan Tarihi Çark, parkın ortasında inşa edilen $14.000 \mathrm{~m}^{21}$ lik gölet ve üzerinde hayvanlar için doğal habitatlar oluşturan küçük adacıklar ile bunları bağlayan köprüler bulunmaktadır (Şekil 2). 


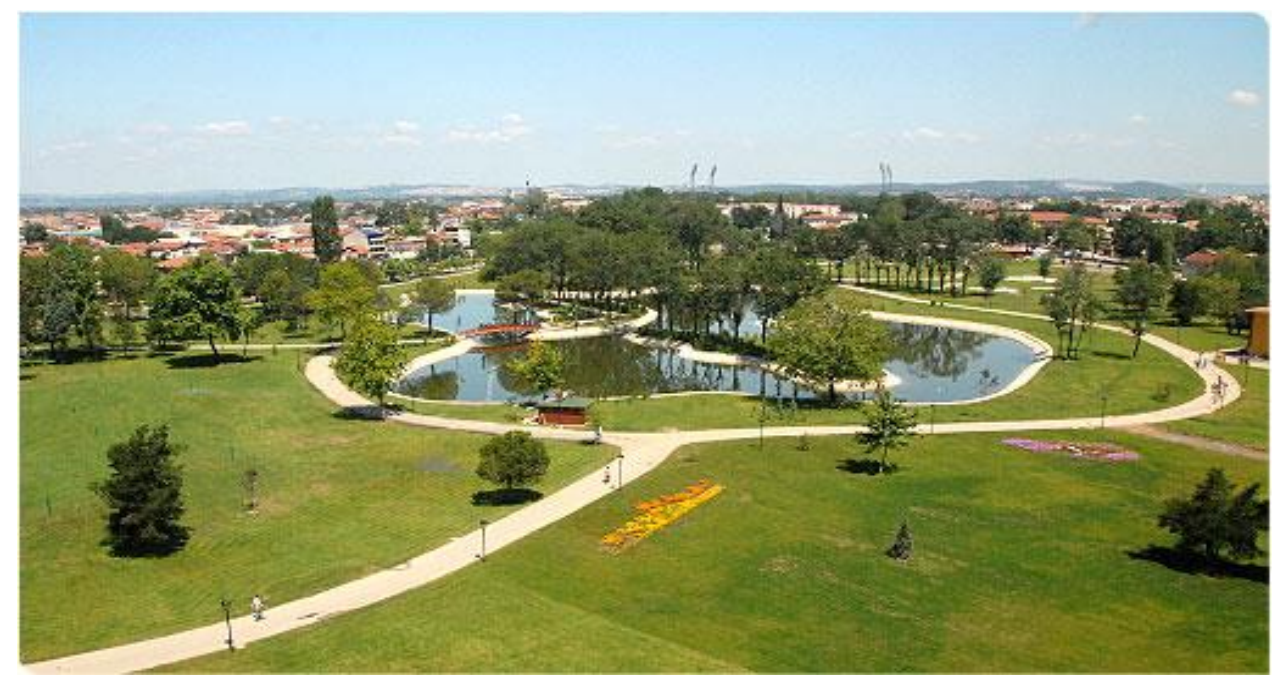

Şekil 2. Kent Park'tan bir görünüm.

Kent Park'ta faaliyette olan iki büfe ve bir kıl çadırı, tenis kortu, kapalı yüzme havuzu, su depoları, çocuk oyun alanları, çay bahçeleri, satış noktaları, Faik Baysal Kütüphanesi, kitap kafe, yel değirmeni, çeşme, kamelyalar, ağaç altı oturma-dinlenme alanları ve güvenlik noktası mevcuttur. Park, konser organizasyonları olmak üzere her sene düzenli olarak yapılan Lale şenliği gibi birçok etkinliğe de ev sahipliği yapmaktadır (Şekil 3).
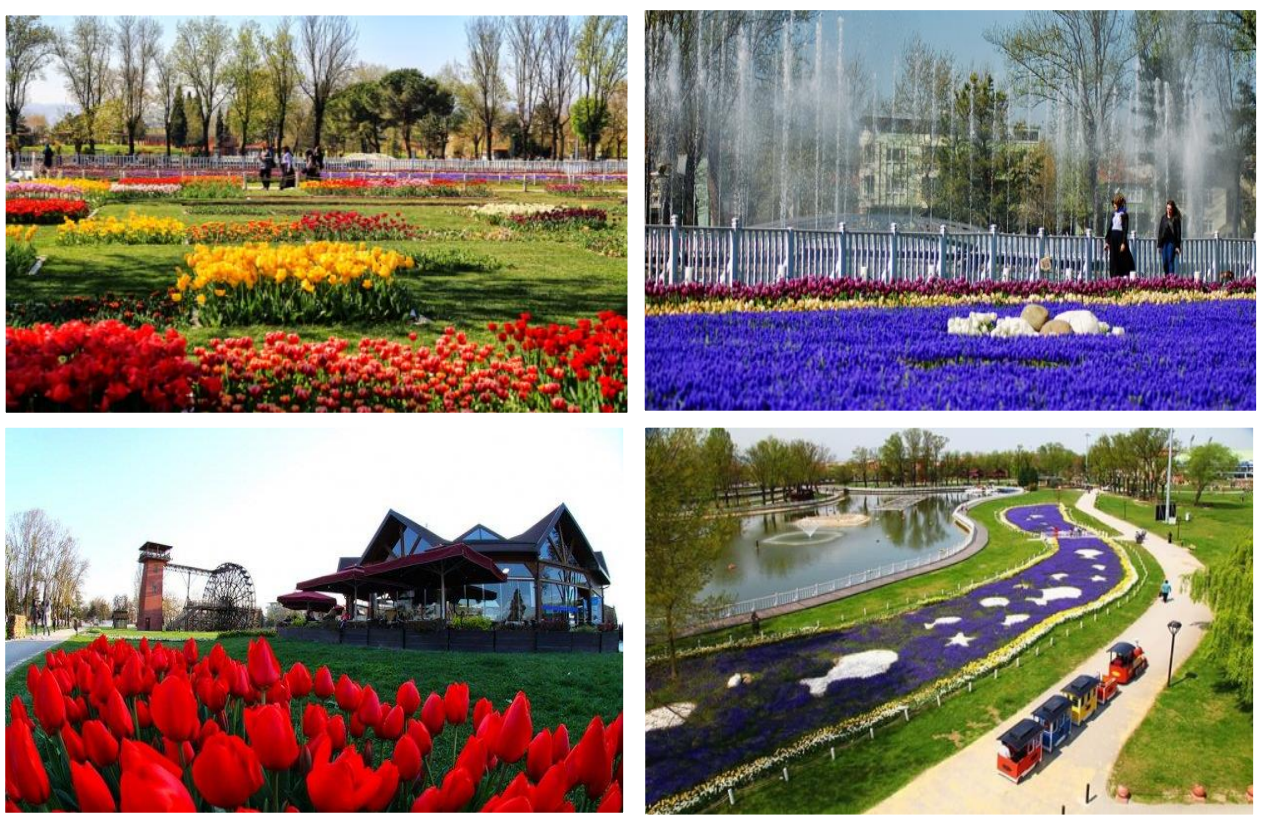

Şekil 3. Kent Park'ta etkinlik alanlarından görünümler.

\section{B. ANKET}

Bu makale ile eş zamanlı olarak yürütülen "Sakarya Kent Park ve Sakarya Park örneklerinde kullanıcı memnuniyeti ve kalite değerlendirmesi" tez çalışması kapsamında Sakarya Kent Park ve Sakarya Park için olmak üzere toplam 440 adet anket yüz yüze görüşme yöntemi ile uygulanmıştır. Aşıkkutlu ve Müderrisoğlu (2010) Ankara Harikalar Diyarı Park'ında rekreasyonel kısıtlayıcıların belirlenmesi 
amacıyla yaptıkları çalışmada 100.000 'den fazla kişinin kullandığı bir alanda 0,05 anlamlılık düzeyinde $\% 5$ 'lik örnekleme hatası dikkate alınarak 250 kişiye anket uygulamışlardır [12]. Kent parkı olma özelliği gösteren çalışma alanının da içerisinde bulunduğu Adapazarı kentinin, 2017 yılı sonu itibariyle kent merkezi nüfusu yaklaşık 272.900 kişidir [13]. Bu veriler doğrultusunda 100.000'den fazla kişinin kullandığı bir alanda 0,05 anlamlılık düzeyinde \%5'lik örnekleme hatası dikkate alınarak Kent Park'ta 240, Sakarya Park'ta 200 kişi olmak üzere iki adet anket uygulanmıştır. Ural ve K1lıç'ın (2005) belirttiği evren büyüklüklerine karşıllk örneklem büyüklügü tablosuna göre 384 adet anketin yapılması bu çalışmadaki evrem-örneklem büyüklüğü ilişkisinin yeterli olduğunu göstermektedir [14]. Bu çalışmada ise tez çalışmasında kullanılan anket sorularının bir kısmı değerlendirilmiştir. Kent Park'ta 120 kişi ile yüz yüze görüşülerek "Kullanıcı memnuniyeti" anketi uygulanmıştır. Anket formu Özkan'ın (2011) çalışmasından derlenmiştir [2]. Uygulanan anket sonucunda kullanıcıların faaliyetlere katılımını etkileyen motivasyon faktörleri, kullanıcı beklenti ve memnuniyetsizliklerinin belirlenmesi hedeflenmiştir. Anket hafta içi ve hafta sonu olmak üzere, 2016 yılı Temmuz-Ekim ayları içerisinde uygulanmıştır.

\section{VERILERIN DE $\breve{G E R L E N D I R I L I M E S I ~}$}

Kent Park kullanıcılarına uygulanan anketler sonucunda elde edilen verilerin istatiksel analizinin yapılması ve değerlendirilmesi sürecinde SPSS 20.0 paket programı kullanılmıştır. Uygulanan anket soruları kapsamında; I. bölümde (Kullanıcı profili) kullanıcı özelliklerinden "yaş, cinsiyet, meslek durumu, eğitim durumu, alana hangi sıklıkla geldikleri ve ne kadar zaman geçirdiklerine" dair alınan cevapların \% olarak frekansları belirlenmiştir. II. bölümde (Kullanıcı memnuniyeti değerlendirmesi), kullanıcıların en çok tercih ettikleri etkinlikleri, kullanıcıların alana gelmeden önce ve geldikten sonraki beklentilerini tespit etmeye yönelik cevaplar alınmıştır. Kullanıcıların gelmeden önce ve geldikten sonraki beklentilerinin tespit edilmesinde beş noktalı Likert Ölçeği'nden yararlanılmış ve "5" kesinlikle katılıyorum, "1" kesinlikle katılmıyorum olarak belirlenmiştir. Çalışmada kullanıcıların alana gelmeden önce ve geldikten sonraki beklentileri karşılaştırılmış ve aralarında benzerlik olup olmadığı Paired Sample T-Testi analizi ile araştırılmıştır. Rekreasyonel faaliyetlere katılımı etkileyen motivasyon faktörlerini belirlemek için faktör analizinden yararlanılmış ve bu faktörlerin güvenilirliğini ortaya koymak için güvenilirlik analizi yapılmıştır. Yapılan faktör analizi sonucunda kullanıcıların rekreasyonel faaliyetlere katılımını motive eden iki adet faktör grubu (Teknik özellikler, Estetik özellikler) belirlenmiştir. III. bölümde ise kentsel açık mekanda kullanıcıların beklentileri ve motivasyon faktörleri, kullanıcı memnuniyeti ve mekan kalitesi açısından değerlendirilmiştir.

\section{BULGULAR VE TARTIȘMA}

\section{A. KULLANICI ÖZELLIKKLERI}

Kent Park'ta yapılan anket çalışması kapsamında kullanıcıların sosyo-demografik özellikleri ve alanı kullanım sıklıkları ile kullanım süreleri incelenmiştir (Tablo 2). 
Tablo 2. Kent Park kullanıcılarının sosyo-demografik özellikleri ve alanı kullanım alışkanlıkları.

\begin{tabular}{|c|c|c|}
\hline \multicolumn{2}{|c|}{ KULLANICI ÖZELLİKLERİ } & YÜZDE DEĞER (\%) \\
\hline \multirow{3}{*}{ YAŞ } & Genç & 63,4 \\
\hline & Erişkin & 34,1 \\
\hline & Yaşl1 & 2,5 \\
\hline \multirow[b]{2}{*}{ CINSIYYET } & Kadın & 62,5 \\
\hline & Erkek & 37,5 \\
\hline \multirow{5}{*}{ EĞİTIM DURUMU } & İlkokul & 1,7 \\
\hline & Ortaokul & 6,7 \\
\hline & Lise & 10 \\
\hline & Önlisans\&Lisans & 72,5 \\
\hline & Yüksek lisans\&Doktora & 9,2 \\
\hline \multirow{7}{*}{ MESLEK DURUMU } & Öğrenci & 66,7 \\
\hline & Serbest meslek & 3,3 \\
\hline & Memur & 6,7 \\
\hline & Ev hanımı & 7,5 \\
\hline & Diğer meslekler & 8,3 \\
\hline & Emekli & 6,7 \\
\hline & Çalışmıyor & 0,8 \\
\hline \multirow{5}{*}{ KULLANIM SIKLIĞI } & Hergün & 5 \\
\hline & Her haftasonu & 10 \\
\hline & Haftada birkaç kez & 10 \\
\hline & Ayda birkaç kez & 36,7 \\
\hline & Yılda birkaç kez & 37,5 \\
\hline \multirow{5}{*}{ KULLANIM SÜRESİ } & Yarım saatten az & 7,5 \\
\hline & Yarım saat & 18,3 \\
\hline & $1-2$ saat & 48,3 \\
\hline & $2-3$ saat & 20,8 \\
\hline & 3 saatten fazla & 5 \\
\hline
\end{tabular}

Kent Park kullanıcılarının en çok tercih ettikleri etkinlikler sırasıyla oturmak-sohbet etmek, tematik bahçeler, farklı spor dalları, piknik yapmak, alışveriş yapmak, yeme-içme etkinliği, suyu seyretmek, diğer aktiviteler, spor-egzersiz yapmak, açık hava gösteri-konseri etkinliği, kitap-gazete okumak ve çocuk oyun etkinliği olarak belirlenmiştir. Kullanıcılar park kullanımını olumsuz yönde etkileyen faktörler sırasıyla en fazla "yeterli zamanımın olmaması, oturduğum yere uzak, gitmemi gerektiren bir nedenim yok, parkın bakımlı ve temiz olmaması, aktivitelerden haberdar değilim, park güvenli değil, sunulan hizmetler kaliteli değil ve ulaşımın pahalı olması" şeklinde tespit edilmiştir.

\section{B. KENTSEL AÇIK MEKANDAKİ KULLANICI MEMNUNIYETINİ ETKILEYEN BEKLENTILER}

Bu bölümde ise 18 sorudan oluşan "Alana gelmeden önce beklentiler" ve "Alana geldikten sonra beklentiler" şeklinde iki alt başlıkta kullanıcıların memnuniyet derecesi ölçülmüştür. Beş noktalı Likert Ölçeği'nden yararlanılmıştır ve "5" Kesinlikle Katılıyorum, "1" Kesinlikle Katılmıyorum olarak belirlenmiştir. Bu beklentiler doğrultusunda mekanların kullanıcı ihtiyaç ve gereksinimlerini karşılayıp karşılamadığı belirlenmiştir. Araştırmada kullanıcıların alana gelmeden önce ve geldikten sonra beklentileri karşılaştırılmış ve aralarında benzerlik olup olmadığ sonucuna göre Paired Samples Test tablosunda yer alan tüm Sig.(2-tailed) değerlerinin 0,05'den küçük 
olduğu görülmektedir. Yani kullanıcıların alana gelmeden önce ve geldikten sonra beklentilerinin ortalamas1 alındığında aralarında fark olduğu tespit edilmiştir. Bu durumda tüm kriterlerde gelmeden önce beklentinin daha fazla olduğu görülmektedir ve kullanıcıların alana geldikten sonra alanın beklentilerini karşılamadıkları sonucuna ulaşılmıştır (Tablo 3).

Tablo 3. Kent Park kullanıcılarının alana gelmeden önce ve geldikten sonraki beklentilerinin karşılaştırılması.

\begin{tabular}{|c|c|c|c|c|c|c|c|c|c|}
\hline \multicolumn{10}{|c|}{ Paired Samples Test } \\
\hline & & \multicolumn{5}{|c|}{ Paired Differences } & \multirow[t]{3}{*}{$\mathbf{t}$} & \multirow[t]{3}{*}{ df } & \multirow{3}{*}{$\begin{array}{l}\text { Sig. (2- } \\
\text { tailed) }\end{array}$} \\
\hline & & \multirow[t]{2}{*}{ Mean } & \multirow[t]{2}{*}{$\begin{array}{c}\text { Std. } \\
\text { Deviation }\end{array}$} & \multirow[t]{2}{*}{$\begin{array}{l}\text { Std. } \\
\text { Error } \\
\text { Mean }\end{array}$} & \multicolumn{2}{|c|}{$\begin{array}{c}\text { 95\% Confidence } \\
\text { Interval of the } \\
\text { Difference } \\
\end{array}$} & & & \\
\hline & & & & & Lower & Upper & & & \\
\hline $\begin{array}{l}\text { Kriter } 1-\mathrm{Bu} \text { alanda bir } \\
\text { etkinlikten bir diğer etkinliğe } \\
\text { rahatlıkla ulaşabiliyorum. }\end{array}$ & $1.4 \mathrm{a}-1.4 \mathrm{~b}$ & 1,40 & ,87 & ,07 & 1,25 & 1,56 & 17,64 & 119 & ,000 \\
\hline $\begin{array}{lrr}\text { Kriter } 2- & \mathrm{Bu} & \text { alandaki } \\
\text { etkinliklerden } & & \text { Park } \\
\text { bütünündeki } & \text { etkinliklere } \\
\text { rahatlıkla ulaşabiliyorum. }\end{array}$ & $1.5 a-1.5 b$ & 1,28 &, 82 & ,07 & 1,13 & 1,43 & 17,10 & 119 &, 000 \\
\hline $\begin{array}{l}\text { Kriter 3- } \mathrm{Bu} \text { alandaki etkinlik } \\
\text { mekanlar1 yeterlidir. }\end{array}$ & $1.6 a-1.6 b$ & 2,06 & 1,09 &, 09 & 1,86 & 2,26 & 20,76 & 119 &, 000 \\
\hline 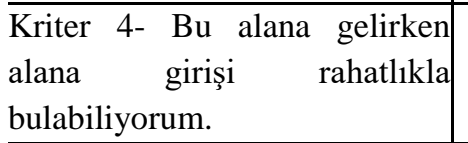 & $1.7 a-1.7 b$ & ,99 & 77 & ,07 & ,85 & 1,13 & 14,06 & 119 &, 000 \\
\hline $\begin{array}{l}\text { Kriter 5- Bu alandaki donatı } \\
\text { elemanları (oturma elemanı, } \\
\text { gölge elemanı, aydınlatma } \\
\text { elemanı, çöp kutusu elemanı) } \\
\text { yeterlidir. }\end{array}$ & $1.8 \mathrm{a}-1.8 \mathrm{~b}$ & 1,84 & 1,18 &, 10 & 1,62 & 2,05 & 17,08 & 119 &, 000 \\
\hline $\begin{array}{l}\text { Kriter 6- Bu alanda donatı } \\
\text { elemanları (oturma elemanı, } \\
\text { gölge elemanı, aydınlatma } \\
\text { elemanı, çöp kutusu elemanı) } \\
\text { rahat ve kullanışlıdır. }\end{array}$ & $1.9 \mathrm{a}-1.9 \mathrm{~b}$ & 1,77 & 1,08 &, 09 & 1,57 & 1,97 & 17,99 & 119 &, 000 \\
\hline $\begin{array}{l}\text { Kriter } 7-\mathrm{Bu} \text { alandaki döşeme } \\
\text { elemanları yürümek için rahat } \\
\text { ve kullanışlıdır. }\end{array}$ & $1.10 \mathrm{a}-1.10 \mathrm{~b}$ & 1,42 & 1,01 & ,09 & 1,24 & 1,60 & 15,33 & 119 &, 000 \\
\hline $\begin{array}{l}\begin{array}{l}\text { Kriter } \\
\text { başka }\end{array} \text { insanların alanı kullanan } \\
\text { güvende olmamı sağlıgor. }\end{array}$ & $1.11 \mathrm{a}-1.11 \mathrm{~b}$ & 1,44 & 1,16 & , 10 & 1,23 & 1,65 & 13,55 & 119 & ,000 \\
\hline $\begin{array}{l}\text { Kriter 9- } \mathrm{Bu} \text { alanı akşamları } \\
\text { rahatlıkla kullanıyorum. }\end{array}$ & $1.12 \mathrm{a}-1.12 \mathrm{~b}$ & 1,90 & 1,18 & , 10 & 1,68 & 2,11 & 17,58 & 119 &, 000 \\
\hline $\begin{array}{l}\text { Kriter } 10-\mathrm{Bu} \text { alandaki donatı } \\
\text { elemanlarını (oturma elemanı, } \\
\text { gölge elemanı, aydınlatma } \\
\text { elemanı, çöp kutusu elemanı) } \\
\text { biçim ve renk açısından } \\
\text { beğeniyorum. }\end{array}$ & $1.13 a-1.13 b$ & 1,57 & 1,06 & ,09 & 1,38 & 1,76 & 16,17 & 119 & ,000 \\
\hline
\end{tabular}




\begin{tabular}{|c|c|c|c|c|c|c|c|c|c|}
\hline 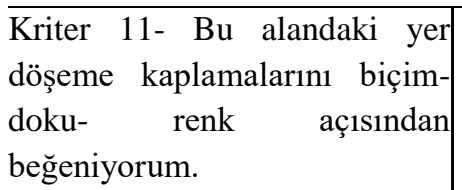 & $1.14 \mathrm{a}-1.14 \mathrm{~b}$ & 1,41 & 1,05 & ,09 & 1,22 & 1,60 & 14,67 & 119 & ,000 \\
\hline $\begin{array}{l}\begin{array}{l}\text { Kriter 12- } \mathrm{Bu} \\
\text { alandandarın yeşil } \\
\text { beğeniyorum. }\end{array} \\
\text { görünümünü }\end{array}$ & $1.15 \mathrm{a}-1.15 \mathrm{~b}$ & ,96 &, 84 & ,07 &, 81 & 1,12 & 12,46 & 119 & ,000 \\
\hline 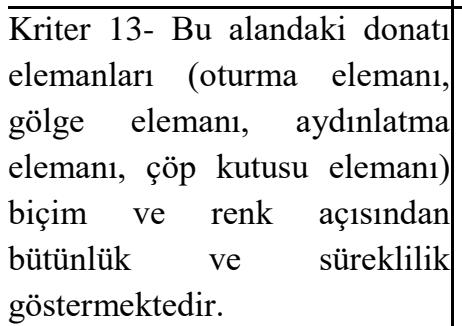 & $1.16 \mathrm{a}-1.16 \mathrm{~b}$ & 1,55 & 1,06 & ,09 & 1,35 & 1,74 & 15,90 & 119 &, 000 \\
\hline $\begin{array}{l}\text { Kriter 14- } \mathrm{Bu} \text { alandaki } \\
\text { döşeme } \\
\text { renk ap̧lamaları biçim ve } \\
\text { süreklilik göstermektedir. }\end{array}$ & $1.17 \mathrm{a}-1.17 \mathrm{~b}$ & 1,45 & 1,02 & ,09 & 1,27 & 1,64 & 15,53 & 119 & ,000 \\
\hline $\begin{array}{lrr}\text { Kriter } & \text { 15- Bu alandaki döşeme } \\
\text { kaplamaları } & \text { temiz } & \text { ve } \\
\text { bakımlıdır. } & & \end{array}$ & $1.18 \mathrm{a}-1.18 \mathrm{~b}$ & 1,79 & 1,08 & ,09 & 1,59 & 1,98 & 18,10 & 119 &, 000 \\
\hline $\begin{array}{l}\text { Kriter 16- Bu alandaki donatı } \\
\text { elemanları (oturma elemanı, } \\
\text { gölge elemanı, aydınlatma } \\
\text { elemanı, çöp kutusu elemanı) } \\
\text { temiz ve bakımlıdır. }\end{array}$ & $1.19 \mathrm{a}-1.19 \mathrm{~b}$ & 1,68 & 1,06 & ,09 & 1,49 & 1,87 & 17,37 & 119 & ,000 \\
\hline $\begin{array}{l}\text { Kriter 17- } \mathrm{Bu} \text { alandaki yeşil } \\
\text { alanlar temiz ve bakımlıdır. }\end{array}$ & $1.20 \mathrm{a}-1.20 \mathrm{~b}$ & 1,57 & 1,04 & ,09 & 1,38 & 1,76 & 16,55 & 119 &, 000 \\
\hline $\begin{array}{l}\text { Kriter 18- } \mathrm{Bu} \text { alan etkinlik } \\
\text { mekanları, donatılar, döşeme } \\
\text { kaplamaları ve yeşil alanların } \\
\text { bütünlüğü açısından memnun } \\
\text { edicidir. }\end{array}$ & $1.21 \mathrm{a}-1.21 \mathrm{~b}$ & 1,65 & ,95 & ,08 & 1,48 & 1,83 & 18,98 & 119 & ,000 \\
\hline
\end{tabular}

a: gelmeden önce beklenti b: geldikten sonra beklenti, $(p<0.05)$

Anket sonuçlarından edinilen bulgulara göre Kent Park kullanıcılarının alana gelmeden önce ve alana geldikten sonra beklentilerinin ortalamalarını alındığında arasında en fazla fark bulunan üç kriter "Bu alandaki etkinlik mekanları yeterlidir (Kriter 3)", "Bu alandaki donat1 elemanları ( oturma elemanı, gölge elemanı, aydınlatma elemanı, çöp kutusu elemanı) yeterlidir (Kriter 5)", "Bu alanı akşamları rahatlıkla kullanıyorum (Kriter 9)" olarak belirlenmiştir. Kullanıcılar kent parkına gelmeden önce alandaki etkinlik mekanlarının ve alandaki donatı elemanlarının yeterli olduğunu düşünmektedir fakat alana geldikten sonra alanın beklentilerini karşılamadıklarını, etkinlik alanlarını ve donatı elemanlarını yetersiz buldukları sonucuna ulaşılmıştır. Ayrıca kullanıcılar kent parkına gelmeden önce alanı akşamları rahatlıkla kullanabileceklerini düşünürken alana geldikten sonra alanı akşamları rahatlıkla kullanamadıkları sonucuna ulaşılmıştır. Kullanıcılar döşeme kaplamaları temiz ve bakımlı olduğunu düşünmektedir fakat alana geldiklerinde öyle olmadığını belirmişlerdir (Kriter 15), donatı elemanlarının rahat ve kullanışlı olmasını beklerken, donatı elemanları konfor açısından beklentilerini karşılamamıştır (Kriter 6), donatı elemanlarının (Kriter 16) ve yeşil alanların (Kriter 18) temiz ve bakımlı olduğunu düşünürken beklenildiği gibi olmadığı sonucuna ulaşılmıştır. 


\section{B. REKREASYONEL FAALIYETLERE KATILIMI ETKILEYEN KULLANICI MOTIVASYONLARI}

Bu çalışmada kullanıcı motivasyonlarının katılıma etkisi üzerine 8 adet kriter değerlendirilmiştir. $\mathrm{Bu}$ kriterleri açıklayabilmek için Faktör analizi yapılmışır ve analiz sonucunda kriterler iki grupta toplanmıştır. Bu faktörler etki derecelerine göre sırasıyla KFII (Teknik özellikler), KFI (Estetik özellikler) olarak gruplanmaktadır. Faktör analizinde 0,5 altındaki faktör değerleri güvenilirliği düşürdüğü ve hiç bir sanal kümede anlamlı bulunmadığı için çıkarılmıştır. Çıkarılan 10 adet kriter sonucunda toplam varyans değeri \%65,173, KMO (Kaiser-Meyer-Olkin) uygunluk değeri 0,855, Bartlett küresellik değeri 594,276 ve Sig. 0,00 ile açıklanmaktadır ve bu değerler analizin açıklanabilirliği açısından oldukça yeterli kabul edilmektedir. Güvenilirlik analizi için Cronbach's alfa tekniği, (kısa adıyla alfa tekniği) en çok kullanılan teknikler arasında yer almaktadır. Güvenilirlik katsayısı 0 ile 1 arasında değerler alır ve bu değer 1'e yaklaştıkça güvenilirlikte artar [15]. Bu çalışma kapsamında kullanıcıları motive eden faktör gruplarının güvenilirliği de Cronbach's alfa değeri ile açıklanmaktadır. Faktör grupları ve analiz verileri Tablo 4'te açıklanmıştır.

Tablo 4. Rekreasyonel faaliyetlere katılımı etkileyen motivasyon faktörleri.

\begin{tabular}{|c|c|c|c|}
\hline MOTİVASYON & $\begin{array}{l}\text { MOTIVASYON } \\
\text { A. Ort. }\end{array}$ & FI & FII \\
\hline $\begin{array}{l}\text { Bu alandaki donatı elemanlarını (oturma elemanı, gölge elemanı, } \\
\text { aydınlatma elemanı, çöp kutusu elemanı) biçim ve renk açısından } \\
\text { beğeniyorum. }\end{array}$ & 3,2250 & ,750 & \\
\hline $\begin{array}{l}\text { Bu alandaki yer döşeme kaplamalarını biçim- doku- renk açısından } \\
\text { beğeniyorum. }\end{array}$ & 3,3417 & ,839 & \\
\hline $\begin{array}{l}\text { Bu alandaki donatı elemanları (oturma elemanı, gölge elemanı, } \\
\text { aydınlatma elemanı, çöp kutusu elemanı) biçim ve renk açısından } \\
\text { bütünlük ve süreklilik göstermektedir. }\end{array}$ & 4,4833 & ,795 & \\
\hline $\begin{array}{l}\text { Bu alandaki yer döşeme kaplamaları biçim ve renk açısından bütünlük } \\
\text { ve süreklilik göstermektedir. }\end{array}$ & 3,3417 & ,786 & \\
\hline $\mathrm{Bu}$ alandaki etkinlik mekanları yeterlidir. & 2,7917 & & ,752 \\
\hline $\begin{array}{l}\text { Bu alandaki donatı elemanları ( oturma elemanı, gölge elemanı, } \\
\text { aydınlatma elemanı, çöp kutusu elemanı) yeterlidir. }\end{array}$ & 3,0667 & & ,789 \\
\hline $\mathrm{Bu}$ alandaki döşeme kaplamaları temiz ve bakımlıdır. & 3,9833 & & ,712 \\
\hline $\begin{array}{l}\text { Bu alandaki donatı elemanları (oturma elemanı, gölge elemanı, } \\
\text { aydınlatma elemanı, çöp kutusu elemanı) temiz ve bakımlıdır. }\end{array}$ & 3,2917 & & ,752 \\
\hline GENEL ARİTMETİK ORTALAMA & & 3,285 & 3,075 \\
\hline ALFA & & ,830 & ,795 \\
\hline ÖZDEĞER & & 3,749 & 1,465 \\
\hline VARIANCE $(\%)$ & & 34,932 & 30,241 \\
\hline
\end{tabular}

I. Faktör (Estetik özellikler) \%34,932 varyansla açıklanmaktadır ve Cronbach's alpha değeri 0,830'dir. Analiz sonucunda ulaşılan alfa değeri bu faktörün yüksek derecede güvenilir olduğunu göstermektedir. Faktöre 4 adet motivasyon kriteri girmektedir. Bu kriterlerin ortak özelliği estetik özellikler ile ilgili olmalarıdır. Yer döşeme kaplamalarının biçim- doku- renk açısından beğenilmesi, alandaki donatı elemanlarının (oturma elemanı, gölge elemanı, aydınlatma elemanı, çöp kutusu elemanı) biçim ve renk açısından beğenilmesi, alandaki donatı ve yer döşeme elemanlarının (oturma elemanı, gölge elemanı, aydınlatma elemanı, çöp kutusu elemanı) biçim ve renk açısından bütünlük ve 
süreklilik göstermesi kullanıcıların katılımını etkileyen motivasyon kriterleri arasında daha fazla etkili olmuştur.

II. Faktör (Teknik özellikler) \%30,241 varyansla açıklanmaktadır ve Cronbach's alpha değeri 0,795'dir. Analiz sonucunda ulaşılan alfa değeri bu faktörün oldukça güvenilir olduğunu göstermektedir. II. Faktöre 4 adet motivasyon kriteri girmektedir. Bu kriterlerin ortak özelliği teknik özellikler ile ilgili olmasıdır. Bu faktörü oluşturan kriterlerden alandaki donatı elemanlarının (oturma elemanı, gölge elemanı, aydınlatma elemanı, çöp kutusu elemanı) yeterli olması, etkinlik mekanlarının yeterli olması, alandaki döşeme kaplamalarının ve donatı elemanlarının (oturma elemanı, gölge elemanı, aydınlatma elemanı, çöp kutusu elemanı) temiz ve bakımlı olması kullanıcıların rekreasyonel faaliyetlere katılımında en fazla etkilidir.

\section{KENT PARK KULLANICILARININ SOSYO-DEMOGRAFIK ÖZELLIKLERI ILE KULLANICI MOTIVASYONLARININ ILIŞKISI}

Kentsel açık mekanlardaki kullanıcıların motivasyonunun rekreasyonel faaliyetlere katılımı üzerine performans kriterleri ve sosyo-demografik özelliklerini belirlemek amacıyla frekans dağılımları belirlenmiştir. Kullanıcıların sosyo-demografik özellikleri ile rekreasyonel faaliyetlere katılımlara motive eden performans kriterleri arasında hangi kriterlerin anlamlı olduğunu belirlemek amaciyla $\chi^{2}$ testi yapılmıştır.

Kullanıcıların Kent Park'taki rekreasyonel faaliyetlere katılımı etkileyen faktörler ve kullanıcı özelliklerinden sadece yaş durumu arasında $\chi 2$ testine göre anlamlı ilişki tespit edilmiştir ve buna göre çıkan sonuç şu şekildedir :

Kent Park'ın estetik özellikleri ile kullanıcı özelliklerinden yaş durumlarına göre istatiksel olarak faklılık tespit edilmiştir (Tablo 5). Genç kullanıcıları estetik kriterler diğer yaş gruplarında olan kullanıcılara göre rekreasyonel faaliyetlere katılımlarını daha fazla etkilemektedir.

Tablo 5. Estetik özellikler ile kullanıcıların yaş durumları arasındaki $\chi^{2}$ testi.

\begin{tabular}{crc}
\hline Estetik Özellikler*Yaş & $\chi^{2}$ & Asymp. Sig. (2-sided) \\
\hline Pearson Chi-Square & 117,061 & 0,021 \\
\hline
\end{tabular}

\section{KENT PARK KULLANICILARININ ALAN KULLANIM SIKLIKLARI VE SÜRELERİ ILEE KULLANICI MOTIVASYONLARININ ILISSKISI}

Kentsel açık mekanlardaki kullanıcıların motivasyonunun rekreasyonel faaliyetlere katılımı üzerine performans kriterleri ve kullanıcıların alanı kullanım sıklıkları ve kullanım sürelerini belirlemek amacıyla frekans dağılımları belirlenmiştir. Kullanıcıların alanı kullanım sıklıkları ve kullanım süreleri ile rekreasyonel faaliyetlere katılımlarını kısıtlayan performans kriterleri arasında hangi kriterlerin anlamlı olduğunu belirlemek amacıyla $\chi 2$ testi yapılmıştır.

Kullanıcıların Kent Park'taki rekreasyonel faaliyetlere katılımı kısıtlayan faktörler ve alanı kullanım sıklıkları ve kullanım süreleri arasındaki ilişkinin $\chi 2$ testine göre çıkan sonuçları şu şekildedir: 
Kent Park'ın teknik özellikleri ile kullanıcıların alanı kullanım süresi arasında istatiksel bakımdan farklılık olduğu görülmektedir (Tablo 6). 1-2 saat arası alanı kullanan kullanıcıları diğer kullanım sürelerinde kullananlara göre rekreasyonel faaliyetlere katılımlarını daha fazla etkilemektedir.

Tablo 6. Teknik özellikler ile kullanıclların alanı kullanım süresi arasındaki $\chi 2$ testi.

\begin{tabular}{ccc}
\hline Teknik Özellikler*Kullanım Süresi & $\chi^{2}$ & Asymp. Sig. (2-sided) \\
\hline Pearson Chi-Square & 86,672 & 0,014 \\
\hline
\end{tabular}

\section{SONUC}

Kullanıııların kentsel açık mekanlardaki kullanıcı memnuniyetini belirlemek amacıyla alana gelmeden önce ve geldikten sonra beklentileri karşılaştırılmış ve sonuç olarak her iki parkta da tüm beklentiler arasında benzerlik olduğu tespit edilmiştir. Kullanıcıların alana gelmeden önceki ve geldikten sonraki beklentilerinin ortalamalarını karşılaştırdığımızda tüm kriterlerde gelmeden önceki beklentilerin yüksek olduğu ve kullanıcılarının beklentilerini karşılamadığı sonucuna ulaşılmıştır. Kent Park'ta en fazla etkinlik mekanları ve donatı elemanlarının yeterliliği açısından kullanıııların beklentilerini karşılamadığı görülmektedir. Ayrıca kullanıcılar akşamları parkı rahatlıkla kullanamadıklarını da belirtmişlerdir.

Kent Park'ta rekreasyonel faaliyetlere katılımı etkileyen motivasyonlar, yapılan faktör analizi sonucunda 8 adet kriter değerlendirilmiştir ve bu kriterler teknik ve estetik kriterler olmak üzere iki grupta toplanmaktadır. Kent Park'ın teknik özellikleri diğer özelliklere göre rekreasyonel faaliyetlere katılımı daha fazla etkilemektedir. Kent Park'ın teknik özellikleri ile ilgili olarak donatı elemanlarının ve etkinlik alanlarının yeterli olması, parktaki döşeme kaplamalarının ve donatı elemanlarının temiz ve bakımlı olması kullanıcıların rekreasyonel faaliyetlere katılımını etkilemektedir. Teknik özellikler ile parkı 1-2 saat arasında kullanan kullanıcılar arasında bir ilişki tespit edilmiştir. Buna göre teknik özellikler, parkı 1-2 saat kullanan kullanıcıları daha fazla etkilemektedir. Kent Park'ın estetik özellikleri ile ilgili olarak yer döşeme kaplamalarının ve donatı elemanlarının biçim-doku-renk açısından beğenilmesi, donatı ve yer döşeme elemanlarının biçim ve renk açısından bütünlük ve süreklilik göstermesi kullanıcıların rekreasyonel faaliyetlere katılımını daha fazla etkilemektedir. Genç kullanıc1ların rekreasyonel faaliyetlere katılımını estetik özellikler daha fazla etkilemektedir.

Cinsiyetin kısıtlayıcılar üzerine etkisini araştırmak amacıyla birçok çalışma yapılmıştır. Kinnaird (1994), Annett et al. (1995)' in araştırmalarında; kadın ve erkek kullanıcıların rekreasyonel faaliyetlere katılımlarının kısıtlayıcılarının etkisiyle farklılık gösterdiği sonucuna ulaşmışlardır ve planlama kararları alınırken her iki grubunda ayrı ayrı düşünülmesi gerektiğini saptamışlardır. Yapılan bu araştırmada erkek kullanıcılar kalabalığın rekreasyonel faaliyetlere katılımlarını kadınlara göre daha fazla kısıtladığını belirtmişlerdir. Çalışmanın başlarında kadınların kalabalıktan erkeklere göre daha fazla sorun yaşayacağını düşünmektedirler fakat çalışmanın sonucunda tam tersi olarak belirlenmiştir. Bunun nedeni, erkeklerin sosyalleşme beklentilerinin kadınlara göre daha az olması şeklinde açıklanabilir [12].

Mekanın yaşanılabilirliği ve kalitesi; kullanıcı ihtiyaç ve gereksinimleri karşısında gösterdiği performansa bağlıdır [7]. Kullanıcı ihtiyaç ve gereksinimlerini karşılayan mekanın performansı 
yükselir, sonuçta kalite sağlanmış olur. Kalite artarsa, mekan karşısında kullanıcının memnuniyeti de artar. Böylelikle daha yaşanılabilir ve kullanılabilir mekanlar meydana gelir.

Sonuç olarak;

- Kullanıcıların beklentilerini karşılamak amacıyla parktaki etkinlik mekanları ve donatı elemanlarının sayısı arttırılmalı, akşamları parkı rahatlıkla ve güvenle kullanabilmeleri için önlemler alınmalidir.

- Kent parktaki döşeme kaplamaları ve donatı elemanlarının temizliği ve bakımı sağlanmalıdır.

- Genç kullanıcıların rekreasyonel faaliyetlere katılımlarının arttırılması için uygun alanlar oluşturulmalıdır.

- Parkın daha fazla kullanılmasını sağlamak amacıyla etkinlik çeşitliliği sağlanmalı, kullanıcıların katılımlarını arttıracak organizasyonlar yapılmalıdır.

- Teknik özellikler alanı 1-2 saat arasında kullanan kullanıcıları daha fazla etkilemektedir. Bu nedenle 1-2 saat arasında kullanan kullanıcıların katılımını arttırmak için teknik özellikler ile ilgili olarak iyileştirmeler yapılmalı ve uygun kullanımlar oluşturulmalıdır.

TEȘEKKÜR : Bu çalışma, 2016.02.01.505 proje numarası ile, Düzce Üniversitesi Bilimsel Araştırma Projeleri (BAP) Koordinatörlüğü tarafından desteklenmiştir.

\section{KAYNAKLAR}

[1] S. Aydınlı, "Mekansal değerlendirmede algısal yargılara dayalı bir model," Doktora tezi, Mimarlık bölümü, İstanbul Teknik Üniversitesi, İstanbul, Türkiye, 1986.

[2] D. G. Özkan, "Kentsel açık mekanlarda kullanım sonrası değerlendirme: Trabzon Sahil Bandı örneği," Yüksek lisans tezi, Peyzaj Mimarlı̆ğ bölümü, Karadeniz Teknik Üniversitesi, Trabzon, Türkiye, 2011.

[3] Z. Ertürk, Tasarım ve Insan Bilimleri, 1. bask1, Trabzon, Türkiye: Karadeniz Teknik Üniversitesi Mimarlık Fakültesi Yayınları, 1979.

[4] W. H. Whyte, The Social Life of Small Urban Spaces, Washington, United States of America: DC: The Conservation Foundation 1980.

[5] S. Carr, M. Francis, L.G. Rivlin ve A.M. Stone, Public Open Spaces, Cambridge, England: Cambridge University Press, 1992.

[6] O. Karagenç, "Toplu konut alanlarında simgesel performansa yönelik kullanım sonrası değerlendirme modeli," Doktora tezi, Mimarlık bölümü, İstanbul Teknik Üniversitesi, İstanbul, Türkiye, 2002

[7] W. F. E. Preiser, H. Z. Robinowitz ve E.T. White, Post Occupancy Evaluation, New York, United States of America: Van Nostrand Reinhold, 1988. 
[8] D.V. Canter, "Evaluating Buildings: Emerging scales and the salience of building elements over contructs," In Architectural Psychology - Proceedings of the Conference, Lund, Sweden: Lund University, 1973.

[9] S. Çerçi, "Konut yakın çevresinin kullanış bilişsel, duyusal ve davranışsal parametrelere bağlı olarak değerlendirilmesi," Doktora tezi, Mimarlık bölümü, İstanbul Teknik Üniversitesi, İstanbul, Türkiye, 1997.

[10] N. E. Altaş, "Kalite kavramı üzerine bir inceleme, fiziksel çevrede kalite parametreleri modeli," İstanbul Teknik Üniversitesi Dergisi, s. 52, ss. 37-48, 1994.

[11] M. Amerigo ve J. L. Arogones, "A Theoretical and Methodological approach to the study of residentiol sutistaction," Journal of Environmentul Psychology, vol. 17, pp. 47-57, 1997.

[12] H. S. Aşıkkutlu ve H. Müderrisoğlu, "Rekreasyonel kısıtlayın belirlenmesi: Ankara Harikalar Diyarı Parkı örneği," Bartın Orman Fakültesi Dergisi, c. 12, s. 18, ss. 11-19, 2010.

[13] Anonim, (06 Mart 2018). Sakarya Valiliği İl Brifingi [Online]. Erişim: http://www.sakarya.gov.tr/kurumlar/sakarya.gov.tr/sakarya/2018br.pdf.

[14] A. Ural ve İ. Kılıç, Bilimsel Araştırma Süreci ve SPSS ile Veri Analizi, Ankara, Türkiye: Detay yayıncılık, 2005.

[15] Z. Arslantürk ve E. H. Arslantürk, Uygulamalı Sosyal Araştırma, 3. baskı, İstanbul, Türkiye: Çamlıca Yayınevi, 2013. 